\title{
Creating moral winds and nurturing moral growth in a P4C classroom community
} in Taiwan

\author{
Dr Jessica Ching-Sze Wang \\ Department of Education, National Chiayi University, Taiwan \\ chingsze@mail.ncyu.edu.tw
}

\begin{abstract}
In this paper I provide a theoretical framework for conceptualising the use of moral education in P4C by drawing on Ann Sharp's work. I use this framework to present my own pedagogical action research in an elementary school in Taiwan. I use both quantitative and qualitative data to document students' moral growth. The results indicate that moral education takes place in a morally stimulating environment, namely, a thinking and caring community of inquiry, with a morally-infused approach to doing P4C in a Confucian society like Taiwan. In this study I employed a Confucian interpretative lens to develop relevant classroom rituals and strategies for creating moral winds in the classroom. The conception of moral education presented in this study provides a glimpse of what P4C classrooms may look like in a global context.
\end{abstract}

\section{Key words}

Ann Sharp, community of inquiry, moral education, P4C

\section{Introduction}

The character (de) of the exemplary person (junzi) is like the wind, while that of the petty person is like the grass. As the wind blows, the grass is sure to bend. (Confucius, Analects, 12.19)

Since its inception in the 1970s, philosophy for children (P4C) has been championed 
as an educational innovation for teaching thinking (Lipman 2003, 2008). Over the decades, researchers have studied the impact of P4C on thinking, achievement and self-esteem, and have found positive outcomes (Trickey \& Topping 2004; Millett \& Tapper 2012). Although P4C can help create competent thinkers and confident learners, Biesta (2011) cautions against the 'instrumentalization of philosophy' behind such rhetoric, and worries that the 'mentalization' of its practice results in an approach which is too 'conceptual and verbal,' 'focusing on arguments and argumentation,' without 'touching the soul' (Biesta 2017, p. 420, 415). In fact, the educational aims of P4C are much broader than that of teaching thinking. The purpose of advancing Deweyan democracy, for instance, is a highly celebrated and contested area in P4C research (Gregory, Haynes \& Murris 2017). In this paper I attempt to explore the link between $\mathrm{P} 4 \mathrm{C}$ and moral education.

By moral education, I do not mean 'learning about morality' through the explicit instruction of moral precepts or the clarification of moral values. What I mean is 'receiving moral lessons' in a morally stimulating environment, namely, a thinking and caring community of inquiry. Moral education takes place indirectly via this socially rich medium, where everyone sits in a circle facing each other and thinking together. This special space helps to cultivate moral and intellectual sensibilities in relational terms and on dialogical grounds. It creates opportunities that stimulate moral reflection and the integration of thinking, feeling, doing and being.

My reason for highlighting the connection between P4C and moral education has much to do with my practical experience as a teacher. As a teacher educator in Taiwan, I have been practicing P4C for five years, beginning soon after I returned from a onemonth field study in Hawaii, working closely with Thomas Jackson (2001). Jackson's emphasis on the creation of an intellectually and emotionally safe community, along with the importance of this insight for moral education, has been an underexplored and under-documented area of $\mathrm{P} 4 \mathrm{C}$ research and scholarship. Although the contribution of $\mathrm{P} 4 \mathrm{C}$ to moral education is widely accepted, the proper conceptualisation of moral education for P4C is not. Scholars often argue that P4C helps to increase ethical understanding and enhance moral judgment (Lipman, Sharp \& Oscanyan 1980; Fisher 1998; Cam 2012). However, can we envision other possibilities than the prevailing cognitive focus? In this study, I locate my point of 
departure in the phenomenon of the circle and explore special modes of association, interaction and communication underlying my classroom practice. I am concerned with change in relationships and behaviors, not just ideas and beliefs. With this said, let us turn to Lipman.

\section{Lipman and the use of $\mathrm{P} 4 \mathrm{C}$ in moral education}

Lipman anticipated that P4C 'could be useful for the purpose of moral education and not just for the improvement of thinking skills' (Lipman 2008, p. 117). He did not want 'children to be a group of little prigs vaunting their virtually infallible logicality,' or thinking merely 'in terms of their own self-interest'. He wanted them to develop a 'capacity of respecting and being open' and to acquire 'the moral qualities that they are expected to model to one another' (2008, p. 117). Lipman asserts that there is something morally problematic if the children in $\mathrm{P} 4 \mathrm{C}$ classes are behaving aggressively and egocentrically. This would fall short of his vision of using $\mathrm{P} 4 \mathrm{C}$ to reconstruct education-education worthy of the name.

If $\mathrm{P} 4 \mathrm{C}$ can indeed be used as a form of moral education, what are its 'brand characteristics'? How does it distinguish itself from traditional didactic approaches that aim to instill moral behaviors and beliefs? Lipman claims that P4C does not just 'help children know what to do,' but also shows them how to do it and gives them practice (Lipman Sharp, \& Oscanyan 1980, p. 160). He asserts that the plots of philosophical novels can show children how to engage in a moral situation, and that the actual classroom community of inquiry can provide practice for open discussion and conflict resolution. 'Without such doing, moral education breaks down' (1980. p. $\mathrm{xx})$.

In a nutshell, moral education in P4C is action-prone or practice-oriented. However, this cannot be achieved without converting traditional classrooms into thinking, caring and loving communities of inquiry. As Lipman recalls,

When later in the sixties I began to think of possible ways of reconstructing education, the idea of a classroom community of inquiry was beginning to germinate in my mind. And when I came to the point of writing about this idea, 
I didn't develop a theory or a proposal but sketched out instead what such a community might look like. The children's philosophical discussions in the classroom were there, the benign, tolerant, appreciative teachers were there, the care of the children and teachers for one another was there. (Lipman 2008, p. 94)

Lipman's depiction of an ideal classroom community is grounded on moral termsprescribing the right sort of teacher-student relationships and the right sort of attitudes and behaviors toward each other.

\section{Ann Sharp and a morally robust conception of the Community of Inquiry}

Apart from Lipman, Ann Sharp, another pioneering P4C scholar, provides a morally robust framework for the pedagogy of a community of inquiry in P4C. In an interview with David Kenney, Lipman acknowledged that Sharp was the major driving force in developing the pedagogy of a classroom community of inquiry (abbreviated as the COI). Her contributions in this regard are worth exploring.

Sharp evidently embraces the idea of community. However, instead of seeing the community as 'nothing more than the total sum of its members,' she regards it as 'an ideal toward which children work by self-correction' (Sharp 2009a, p. 305). According to Phil Cam (2018), Sharp gives more emphasis to 'the community aspect,' whereas Lipman is more concerned with the inquiry aspect, or 'the intellectual side' (p. 33). Laverty and Gregory (2018) note that from her readings in feminism, aesthetic theory, and ecumenical spirituality, Sharp developed a finely attuned moral sensibility by which she perceives nuanced meanings about the community of inquiry.

Sharp (2009a) contends that the community of inquiry is not a given, but an achievement-'an ideal' of 'soul-making,' as she puts it (p. 305). Once achieved, it allows the participants 'to grow as persons'-authentic persons 'striving and struggling to achieve understanding of themselves, each other, and the world around them' (p. 305). The creation of such a community takes time and requires the voluntary and highly conscientious efforts of every participating member in the community. The dynamic process of forming a community nurtures a sense of moral cultivation, 
centering on the harmonious give and take of relationships at every moment of inquiry. In the following, I analyse the core moral features defined by Sharp, highlighting those that are most relevant to the follow-up discussion of my case study in Taiwan.

\section{Core moral features of P4C}

\section{1. 'Going visiting' and 'Putting the ego in perspective'}

Thinking alone and thinking along with others are different matters. In the latter, one is doomed to experience disorientation, discomfort, or even resistance from people who think differently. Thinking together is essentially a deep form of communication across differences through open inquiry and ongoing dialogue. Dialogue cannot go on without people relating to one another, otherwise it degenerates into a disconnected series of solipsistic talks dominated by a few individuals. Knowing that the experience of 'encountering the other' is an existential certainty in P4C, Sharp borrowed from Hannah Arendt the concept of 'going visiting' to emphasise the moral imperative of encountering and understanding differences. As Sharp contends, 'going visiting is what children do ... when they share each other's perspectives and try to build some bridges between their different ways of understanding a situation' (2009b, p. 324). As she elaborates, 'Behind each of these different perspectives lies a world view that must be understood from the inside' (p. 326). Going visiting means 'entering into the worlds of different people with different views, listening attentively to their stories, trying to figure out the worldview from which they are coming, and how they might see you and your perspective as strange' (pp. 324-325).

The nature of 'going visiting' is other-regarding rather than self-centered. Participants have to 'learn to put the ego in perspective,' and to overcome 'preoccupation with self' and 'a narcissism that blocks their ability to listen to one another or take each other's perspectives into account' (Sharp 2009a, p. 301). Sharp (2007) takes 'non-egocentricity' as 'the characteristic of persons who are wise and free' and sees the community of inquiry as the paradigm for cultivating wisdom (p. 11). However, progress in this direction is 'an outgrowth of the group work' (Sharp 2009a, p. 301), rather than the 
outcome of individual successes. It involves a slow process for all to experience and appreciate a way of being in the world without putting oneself in the center of the world.

\section{Ensuring equalitarianism and developing loyalty}

The community of inquiry is a form of life in which children learn how to share power and to collaborate, rather than to compete or to dominate. Sharp (2009a) asserts that 'as the children become confident and secure in mastering the skills of communal inquiry itself, they should also become more sensitive to the importance of involving all in the dialogue and taking care of each member's individual growth' (p. 301). Apart from the inquiry itself, it is 'loyalty and a growing solidarity' that holds the community of inquiry together.

Such a community is held together by the students' consciousness and acceptance of the fact that their participation is necessary for everyone's growth, intellectually, emotionally and socially, and by their loyalty to the group itself. It is such consciousness that is responsible for the child's silencing him/herself at times for the good of the group, or another child's offering a provocative alternative position for the good of the inquiry, or another child's questioning the dominance of some members of the group at the expense of others who are less aggressive (Sharp 2009a, p. 305).

Here loyalty does not mean servitude, but rather a sense of solidarity. Children become loyal to the community because they 'come to place a special value on it' (Sharp 2009a, p. 305); they care about the values that regulate their activity in the group, and they care about its members and their growth. 'If they could no longer participate, they would feel they had lost something very precious that is essential to their own growth and happiness' (p. 305).

\section{Participating in ritualised action}

Sharp regards the praxis of a community of inquiry as a form of ritual participation. She draws from Confucius's concept of propriety $(l i)$ to highlight the importance of 'rule-bound and form-giving acts' which govern human relations and prescribe 
respectful conduct. These rituals are to be repetitively performed by all members of the group in each class session, with 'their efficacy lying precisely in their being in accord with various rules, while at the same time fostering the moral growth of the practitioners' (Sharp 2007, p. 5).

As Confucius taught, such ritual is not only aimed at understanding; it is also aimed at becoming good persons. It is through $l i$, or ritual action, that we learn how to express benevolence towards others. It is also through ritual that we foster our own development in terms of eschewing power over others, development of loyalty to the group and overcoming narcissism. (Sharp 2007, p. 8)

In $\mathrm{P} 4 \mathrm{C}$, these ritualised actions usually include presenting of the stimulus for inquiry, eliciting questions, voting, inquiring, turn-taking, building ideas, and evaluating.

\section{Gaps between theories-Challenges in practice}

Although the idea of a community of inquiry is replete with moral meanings, it is bound to fall short in actual practice. Recent research has pointed to certain limitations in fulfilling the moral ideal of 'going visiting'. For instance, Chetty and Suissa (2017) point out that race is a 'no-go area' in $\mathrm{P} 4 \mathrm{C}$, and that it is difficult to really 'encounter the other', that is, the 'other than white' (Chetty \& Suissa 2017). Reed-Sandoval and Sykes (2017) have also called attention to the problem with meeting the ethically other, such as Native Americans. A high level of 'discomfort' or disorientation may account for the existence of such limitations in P4C classroom practice (Chetty \& Suissa 2017).

Although one can also find success stories that demonstrate the power of P4C to create democratic experiences for students, such as in Makaiau's (2017) research and that of my own (Wang 2015/2016), the moral ideals of egalitarianism and solidarity are generally hard to achieve. We see that in reality, the ideal seedbed of democracy can turn out to be a recalcitrant classroom (Turgeon 1998) with reluctant and disruptive students. Although certain remedies or activities that focus on community building and dialogue enhancement, such as games and role-playing, have been proposed to 'coach the problem' and to 'move beyond hostility toward philosophy,' Burgh and 
Yorshansky (2011) contend that these approaches are insufficient because they fail to address the power dynamics of the group (p. 455). This will require the pedagogic actions of teachers who 'recognize that students bring power-related behaviors to the classroom,' can 'interpret the emotional state,' can attend to 'the emotional life of the group,' can 'deal with power and the distribution of power as a resource,' and ultimately turn conflicts and threats into opportunities of growth (2011, p. 455, p. 450).

On the other hand, the habituation and internalisation of ritualised action in P4C takes time, but time is not always enough. The question of just how much time is needed is hard to tell, but the time factor can greatly affect the outcome of P4C practice. Kyle (1987) shared her 'not-a-success-story' doing P4C with a group of gifted students in a summer school setting. Her experience reveals the difficulty of forming a community of inquiry - which she attributed to the lack of time for an initiation period and 'the self-containment attitude of gifted students' (p. 16). Likewise, Glina (2009) argues that in theory P4C can help alleviate the problem of bullying, but she failed to find positive results in her quasi-experimental quantitative research. In her research, she attempted to measure the prosocial behaviors of students taking P4C classes-but only for eight one-hour sessions (Glina 2015). When P4C practitioners and researchers are in a rush to reap the cognitive and social benefits of $\mathrm{P} 4 \mathrm{C}$, they are likely to meet real challenges. This 'hurriedness' to get somewhere contrasts sharply with Jackson's insistence 'on not being in a rush' (2004, p. 4). Sharp (1987) once also expressed the same concern when she met a teacher who claimed to have truly experienced 'a community of inquiry' - only after attending a workshop of a mere seven days. Sharp reported feeling 'a pang of revulsion' (p. 37) upon hearing such a 'self-satisfying' remark (p. 44).

In addition, after three generations of $\mathrm{P} 4 \mathrm{C}$ practice, we find significant gaps between the different conceptions of its value. Take the most recent literature as an example. Some argue that 'developing communication skills, learning skills, patience, tolerance of difference, and respect for others' are 'the side effects' of $\mathrm{P} 4 \mathrm{C}$, whereas the real business is 'only to be achieved by philosophizing' (McCall \& Weijers 2017, p. 91). On the contrary, others prioritise the development of trust, which is seen as an intellectual virtue (Haynes 2018; D'Olimpio 2018). Undoubtedly, Lipman's inspirational vision to merge philosophy and education will continue to be debated, readapted, and renewed by different generations of P4C-ers - and I take this to be a healthy sign that it is still 
alive, and very much alive, with many new possibilities in the hands of people with different aspirations and dreams.

My P4C class represents my own aspiration to nurture the moral growth of all members and my belief that the epistemic progress will follow suit as long as the community is going in the right moral direction. In the following section, I sketch out the broader intellectual resources and pedagogical strategies that illuminate my morally-infused approach to P4C.

\section{My morally-infused approach to P4C}

As noted above, my P4C mentor was Thomas Jackson. I owe a huge debt to him for his insightful guidance on a morally-infused approach to P4C (Jackson 2001, 2004, 2012). My Confucian moral sensitivity also informed and sharpened my practice. Blending influences from the East and the West, I have augmented my P4C classroom rituals with aesthetic and kinesthetic elements.

My class begins with the ritual of singing the P4C song that I created, with the lyrics reflecting our moral ethos and community rules. ${ }^{1}$ Each class ends with the ritual activity called 'applaud or critique'. In this activity, students are given the opportunity to applaud or critique a deed performed by oneself or a classmate, such as courageously speaking for the first time, listening attentively, or sincerely sharing one's experience. They can also critique others and respectfully remind them not to side talk. This ritual activity reflects the Confucian emphasis on self-reflection and social learning. Confucius taught that we can potentially receive a moral lesson from anyone around us. As he put it, 'In strolling in the company of just two other persons, I am bound to find a teacher. Identifying their strengths, I follow them, and identifying their weaknesses, I reform myself accordingly' (Analects, 7.22). This ritual activity

\footnotetext{
1 The moral ethos and classroom rules are encapsulated in what I call 'The Three No-s and Five More-s,' together reflecting P4C's thinking and communicative moves and expressed using what I call 'The Thinking Hand Signals' (adapted from Thomas Jackson's Thinker's Toolkit and Magic Words). The former refers to 'no bickering, no ridiculing, no mind-wandering', and the latter refers to 'more talking', 'more listening', 'more phrasing', 'more questioning' and 'more respect'. The latter includes gestures for expressing 'I don't understand,' showing appreciation, needing an example, offering a counter example, alerting a possible digression, identifying inferences, detecting assumptions, speaking more loudly, and expressing doubt about whether what is said is true.
} 
empowers individual students with morally praiseworthy conduct and reminds others to follow suit. It also gives students a clear sense of what to expect and how to conduct themselves accordingly.

The moral ideal of 'going visiting' also resonates well with the Confucian notion of 'understanding others' (zhi-ren). As Confucius said, rather than being vexed when others do not understand us, we ought to be vexed when it is we who fail to understand others (Analects, 1.16). Confucius also said that benevolence (ren) is embodied in loving others through understanding them (Analects, 12.22). However, understanding others is not easy. Those who have done P4C with children will know the difficulty of getting at what they mean by what they say. Patience, sympathy and imagination are needed to understand, not only literal meanings, but also connections and implications.

In this process, one needs to practice 'linguistic hospitality' - 'the practice of opening one's language to welcome what is foreign to dwell within it' (Davidson 2012, p. 7). According to Paul Ricoeur, this is a form of intra-linguistic translation that is needed 'when speakers of the same language - due to their age, race, gender, social status, or life experiences-find it difficult, if not impossible, to communicate with one another in spite of a shared language' (Davidson 2012, p. 5-6). By practicing linguistic hospitality and helping each other translate words into ideas, we make everyone in the community circle feel at home-and be understood.

Going visiting, learning to put the ego in perspective, ensuring egalitarianism, and practicing linguistic hospitality - all of these help to explain the moral and intellectual ideals that regulate the activities of my classroom community of inquiry. The moral effect can be best captured by a saying of Confucius in the Analects: 'The character (de) of the exemplary person (junzi) is like the wind, while that of the petty person is like the grass. As the wind blows, the grass is sure to bend' (Analects, 12.19). My case study will demonstrate the power of collective moral examples-with everyone potentially being a moral exemplar of some sort-thus creating moral winds and the ensuing bending of the grass. 


\section{Creating moral winds and nurturing moral growth}

\section{Setting, participants and curriculum}

This research was carried out at an elementary school in a rural area of southern Taiwan, officially classified as an 'education priority area' where students are considered to be culturally disadvantaged in comparison to those in the cities. The research began when the student participants were in the fifth grade (11 years old) and ended three semesters later when they graduated. They had one P4C class per week, forty minutes each time. Our teaching team included myself as the main facilitator and curriculum designer, the homeroom teacher, and three undergraduate assistants serving as co-facilitators and co-inquirers. I was also responsible for helping the teaching team reflect upon the teaching process. Our classroom inquiries were generated by the students' own questions reflecting their philosophical wonderment, life puzzles, and schooling issues - an approach I have elsewhere described as 'curriculum-less P4C' (Wang 2018, p. 73).

\section{Data sources, collection, and analysis}

To collect data, I had each class videotaped and had students fill out learning sheets for each class. I also created a shared Google document where the members of our teaching team entered class records, notes, questions and reflections - a methodology I adopted from previous work by my overseas P4C colleagues (Makaiau et al. 2017); the data collected there will be cited below as GOO/Date. At the end of each semester I distributed a questionnaire, a modified version of Lu Leng's (2015) questionnaire, and these will be cited as QU1, QU2 and QU3. The questionnaire has 35 items on a five-point Likert scale (with 1-5 respectively indicating: strongly disagree, disagree, unsure, agree, strongly agree) and 5-7 open-ended questions. When necessary, I also conducted interviews to check on the students' progress, and I also entered these records in the Google document. The students' learning sheets for each class discussion were also collected and will be cited as LS/Date. In analysing the data, I employed both quantitative and qualitative methods to develop relevant themes about the participants' moral growth. 


\section{Findings and discussion}

Here I combine the findings and discussion sections together and report quantitative and qualitative findings side by side in order to allow for a narrative account later which captures the power of moral growth in P4C.

According to the quantitative data, the students made moral progress each semester, most evidently in their ability to listen, to respect and understand each other, and to help each other learn, as indicated in their responses to the questionnaire items measuring the level of respect, openness and solidarity (see the chart below).

Questionnaire item

\begin{tabular}{|c|c|c|c|}
\hline & 1 & 2 & 3 \\
\hline I listen attentively to understand my peers. & 3.63 & 4.60 & 4.68 \\
\hline $\begin{array}{l}\text { Listening to my peers helps me understand my own } \\
\text { thinking. }\end{array}$ & 3.88 & 4.40 & 4.64 \\
\hline I am responsible for my peers' learning. & 3.88 & 4.30 & 4.32 \\
\hline It is a pleasure to share my thoughts with others. & 3.63 & 4.20 & 4.23 \\
\hline I value my classmates' ideas. & 3.88 & 4.45 & 4.45 \\
\hline $\begin{array}{l}\text { When other classmates have difficulty expressing their } \\
\text { views, I try to use my own experience and imagination } \\
\text { to understand them. }\end{array}$ & 3.88 & 4.15 & 4.23 \\
\hline I will try to reduce my prejudice. & 4.00 & 4.15 & 4.55 \\
\hline
\end{tabular}

The qualitative data also attests to their moral learning, most strongly in the intrapersonal and inter-personal domains, such as learning to respect those whom they may consider different, slow or strange, and the transfer of such learning to non-P4C contexts:

When I was in fourth grade, I didn't understand what it means to respect others. I used to be very straightforward, and I might have made other people feel disrespected. But now, before I state my opinion, I always pause, and first consider whether I am being respectful. (S10, QU2) 
Sometimes when I heard a certain classmate speaking in a strange way, I would refuse to listen to him. But later I realized that the problem might be that what he says is difficult to grasp immediately. I have to respect him more. (S3, QU2)

When some of my classmates are slow in expressing their viewpoints, I shouldn't be impatient. (S14, QU2)

Now when I see my classmates misinterpreting math questions, I don't laugh at them. (S11, QU2)

Both the quantitative and qualitative data reveal that $\mathrm{P} 4 \mathrm{C}^{\prime} \mathrm{s}$ moral ethos of 'inclusiveness' and 'social solidarity' (Lipman 2004) and of 'loyalty' (Sharp 2009a) were being valued and practiced in my classroom community. When encountering 'the other', the students had learned to 'put the ego in perspective' and 'go visiting.'

The key to students' moral learning lies in learning to listen, and listening to understand. In fact, listening is not merely a technical skill or a 'side benefit' of P4C, as McCall (2017, p. 91) suggests. Listening exposes students to a different way of being in the world, a new way of relating to others, and constitutes a reflective process of transforming oneself. As Sharp (2009a) indicates, 'One test of having learned to put one's ego in perspective is whether one can listen attentively and build on the ideas of others' (p. 304). This process is not as easy as it seems, particularly for those who are verbally dominant and tend to talk a lot in class. As one vocal girl revealed in her learning sheet, 'There were so many thoughts coming out of my mind, but I knew that I had to respect everyone, so I only spoke twice' (S9, LS/2016/10/19). And another talkative boy wrote, 'In today's class, there was so much I wanted to say, but I also knew that I had to let others talk as well. Alas! Alas!' (S22, LS/2016/12/12).

However, this learning does not happen automatically. It requires a kind of pedagogical sensitivity on the part of the facilitators that allows them to attend to the power dynamics of the class, to interpret the emotional state of the group, as Burgh and Yorshansky (2011) put it, and to arrange pedagogical actions accordingly. During the process of helping to consolidate the community, I designed some games and reflective activities to address the problem of unequal participation. As one student wrote, 'In the first semester, I always rushed to speak, but after we played the game, I 
learned to listen, and I now understand the importance of listening' (S14, QU2).

In addition, whenever necessary, we also took time in class to address interpersonal conflicts. For example, in the meta-reflection session of the first semester, the class had a very interesting discussion about the issue of unequal participation. One student asked whether those who rarely talk might be forgotten by the class and hence suffer a lower sense of belonging. At the end of the discussion, every student was invited to share whether they felt a sense of belonging in the P4C class and why. One verbally active girl stated that a sense of belonging doesn't come just by talking a lot, but rather by having one's ideas carefully heard and built upon by others in the community. Another vocal boy said that he did not have a high sense of belonging, because he often struggled between talking and letting others talk (GOO/2016/5/17). His predicament was very real, but he later learned to find a nice balance. He also learned to exercise 'linguistic hospitality' by helping to translate unintelligible comments into clearer statements, thus making himself a moral role model for his classmates (S5, QU2).

When the class achieved a stage of equal participation, the students really started to enjoy the discussion, and even treasure that special time 'when we are all learning together' (S5, QU1). Indeed, it is this growing sense of loyalty and solidarity that holds the community of inquiry together. As Sharp (1987) notes, 'When [children] truly collaborate, it is a matter of we, not just personal success. It's a matter of our ideas, our achievements and our progress' (p. 43). When asked about the impact of P4C on their class, the students said that P4C 'makes our class more harmonious' (S23, QU1); 'our classroom atmosphere is more fun' (S18, QU1); 'we try to resolve problems by thinking together' (S7, QU1); and 'we have a better understanding of each other's thoughts' (S9, QU1).

Most significantly, the initial focus on creating an intellectually and emotionally safe community in the first semester gradually led to the improvement of student thinking. When the same question was asked again in the second semester, more and more students referred to the improvement in their thinking. Typical comments were: 'We talk more deeply and we enjoy thinking more' (S13, QU2); 'P4C helped us think better' (S7, QU2); 'We have become better at thinking' (S14, QU2); 'We love thinking more and have become better at it' (S15, QU2); 'We can think better' (S16, QU2); 'We have 
become better at understanding things and asking questions' (S11, QU2); and 'We exercised our brains more, and our brains have become more flexible and now run faster' (S17, QU2).

In the third semester, when the students were asked, 'What would have been the result if I had not taken P4C?' they responded consistently in terms of the impact of thinking on their lives. Typical comments were: 'I would not have learned to use multiple perspectives to examine a question' (S9, QU3); 'I would still have seen things too simplistically, without trying to think more deeply' (S12, QU3); 'I would have passively waited for others to tell me the answers' (S19, QU3); 'I would have continued failing to ask others questions when I don't understand' (S16, QU3); 'I would still dislike thinking' (S7, QU3); 'I would still consider thinking to be difficult, when in fact it is not; it can help me to learn and grow' (S20, QU3); and 'I would still be unable to think and to ask questions' (S21, QU3). For the questionnaire item 'More students should be given the chance to take P4C classes,' the mean response was 4.95 (QU3).

I interviewed a few students and asked about the key reasons for their progress. One student commented, 'When you see others making progress, this makes you want to improve as well' (S5, GOO/2017/1/19). In the questionnaires, I also asked the students to identify which of their peers seemed to be making obvious progress. Many of them referred to a shy girl who hardly spoke and who, when she did speak, could hardly be heard. However, the teacher, facilitators and her classmates trusted that she could overcome her fear of speaking, so they usually patiently waited for her to speak. When she finally found the courage to speak in an audible voice, she sent a powerfully encouraging message to the class: when there is trust, there is hope. These were precious moments of respectful silence and courageous presence that demonstrate communal love and care. The teachers modeled the target behaviors, and the students followed suit. As one student said in an interesting way, the most impressive experience in $\mathrm{P} 4 \mathrm{C}$ is to see 'the small classmates become middle classmates, and the big classmates become small classmates' (S5-QU3). In light of the great emphasis put on competition in contemporary schooling, where the strong remain strong, and the weak remain weak, such a genuine remark from a child is worth pondering.

The collective power of moral examples-arising from the students themselves, in various ways, in different morally significant directions-became the major force that 
shaped the moral learning in my classroom community.

Indeed, by endeavoring to create a mature community of inquiry, we were creating moral winds that nurture the moral growth of students, leaving none unaffected.

\section{The power of moral winds: A narrative account}

In this section, I would like to share an inspirational story illustrating how the influence of moral winds helps to transform power relations in the classroom and to resolve interpersonal conflicts. As Burgh and Yorshansky (2011) point out, students do bring power-related issues to the community of inquiry; hence it is important to attend to these issues in order to realise the democratic goal in P4C.

In my class a boy named John was disliked by many of his classmates. When he spoke, they were quick to disagree with him. I remember that on our second day of class, as I was going through the classroom rules and ethos, explaining the importance of 'no ridiculing,' John raised his hand and provided a personal example. He indirectly referred to another boy named Kevin, who had made fun of him because he took powdered medicine instead of pills. John interpreted Kevin's question 'Why don't you take pills?' as a form of ridicule. After hearing John, I re-phrased his comment and asked Kevin to respond to John. Kevin explained that he had no intention to ridicule John; he simply found it strange for a fifth-grader to be still taking powdered medicine. John explained that he had always had difficulty swallowing pills. Then I asked if anyone in our community circle also found it difficult to swallow pills. A couple of hands went up. One was that of my teaching assistant. She recounted that when she was younger she once had a bad experience with swallowing pills, and said that it was so traumatic that she still had a fear of pills. Then I turned to John and asked if he could accept Kevin's explanation. John said he could. This conflict was genially resolved-with everyone learning to understand that different people have had different experiences, and thus have different viewpoints. I was very touched when I later learned that my education undergraduate student had exaggerated her story in order to show sympathy to John and to make his behavior sound more plausible to his peers (GOO/2016/3/7). Gentle gestures such as these abounded in our P4C class. It 
was the kind of openness and love that the teacher and facilitators demonstrated to students that created a modeling effect for the class.

I also learned that John had a linguistic weakness. He could be very imaginative, but he could not express his ideas clearly. Very often I had to stretch my imagination in order to understand and translate what he meant; I also had to add additional comments to refine what he said. In one of the interviews, one boy named Leo said that when John talked, he could hardly understand him. But when I helped translate John's language into intelligible statements, Leo began to see that he actually might have a good point. In the same interview, a girl named Jen expressed a strong dislike for John and said that she could not possibly befriend him. She even refused to sit beside John and hoped that the teacher could understand her (S23-LS2016/2/18). However, the teacher-facilitator's positive attitude toward John seemed to have affected Jen. She once raised a thoughtful question in her learning sheet: 'How come teachers can accept every student?' (S23-LS 2016/4/10). However, Jen was very impressed by Leo's gradual change of attitude toward John and his willingness to befriend John (S23, QU3). Leo's behavior had an impact on Jen. In one class session, I was very surprised to find Jen practicing linguistic hospitality toward John by asking questions to clarify what he meant, rather than hastily disagreeing. This observation was confirmed in John's last questionnaire, where he wrote that Leo and Jen and some other people in the class 'treat me more friendly now' (S18, QU3).

In fact, our teaching team had long been aware of the interpersonal conflicts between John and his classmates. John was like 'the alienated other,' and our teaching team was eager to find ways to help the class recognise and accept his 'otherness' - while also helping John to understand others' issues and concerns. However, we were also aware that any rushed action would make the matter worse. So we waited until the community became more mature and until there was more mutual trust. Surprisingly, when the class finally decided to confront the problem of John's 'otherness,' they were behaving rather maturely. John was surprisingly open with his classmates as well, and he tried to provide some reasons for this 'otherness.' He even thanked the class for being willing to listen. Indeed, Burgh and Yorshansky (2011) were right about the necessity of attending to the emotional life of the community and turning conflicts into resources for growth. Openly confronting power-related issues in the community 
can truly provide opportunities for growth and lead to better understanding, despite some heatedness in the process.

\section{Conclusion}

My case study in Taiwan shows that moral education in a P4C community of inquiry arises not so much from the topics raised and discussed in class, as from a mode of interpersonal association and behavioral coordination in the classroom that allows teachers and students to experience a different way of being in the world and a new way of relating to each other in that world. It is a more humane way of being together and of getting to understand each other as unique human individuals with different experiences, strengths and weaknesses.

I applaud P4C teachers all over the world for taking the time to create a special place in schools for open inquiry and collaborative dialogue, despite the overcrowded curriculum focusing on educating students' brains, rather than nurturing their moral growth. As I look back, I found that my P4C experiment could not have been successful without the support of the homeroom teacher and my undergraduate students, whom, taken all together, played an important role in modeling P4C's moral ethos and corresponding behaviors. As I re-read the classroom records and reflections by our teaching team, I was often touched by their expressions of appreciation for the P4C class as a special time and place to learn from the students and to nurture their voices. It is this deep sense of humility and respect for children that permeated our P4C work.

On the last day of class, the students arranged a special farewell party and gave each of us a display board with thank-you notes from each of the students. What a special day! As Friedrich Freobel says, education is nothing but love and example. This is how P4C plants the seeds of moral education. And my hope is that those doing philosophy for children will set themselves as moral role models for their students, and thereby practice what they preach. Indeed, as the Confucius's quote aptly reminds us, when we can truly model ourselves as 'junzi' (exemplary persons) and create moral winds in the class, we can surely expect our students to 'bend like the grass' (Analects, 12.19). 


\section{Acknowledgment}

I want to thank the members in my P4C teaching team: Pinliang Pan, Peiyu Zhu, Yanhua Li, Tingwei Zeng, Jianwen Zeng and Yijing Huang, for their devotion and support.

\section{References}

Biesta, G (2017) Touching the soul? Exploring an alternative outlook for philosophical work with children and young people. Childhood and Philosophy, 13(28), pp. 41552.

Biesta, G (2011) Philosophy, exposure, and children: How to resist the instrumentalisation of philosophy in education. Journal of Philosophy of Education, 45(2), pp. 305-319.

Burgh, G \& Yorshansky, M (2011) Communities of inquiry: Politics, power and group dynamics. Educational Philosophy and Theory, 43(5), pp. 437-452.

Cam, P (2012) A new approach to moral education. Camberwell, Vic, ACER Press.

Cam, P (2018) The theory of education made flesh. In MR Gregory \& M Laverty (eds) In community of inquiry with Ann Margaret Sharp: Childhood, philosophy and education. New York, NY, Routledge, pp. 29-37.

Chetty, D \& Suissa, J (2017) No go areas: Racism and discomfort in the community of inquiry. In MR Gregory, J Haynes \& K Murris (eds) The Routledge international handbook of Philosophy for Children. London, UK, Routledge, pp. 11-18.

D'Olimpio, L (2018) Trust as a virtue in education. Educational Philosophy and Theory, 50(2), pp. 193-202.

Davidson, S (2012) Linguistic hospitality: The task of translation in Ricoeur and Levinas. Aanalecta Hermenutica, 4, pp. 1-14. 
Fisher, R (1998) Teaching thinking: Philosophical enquiry in the classroom. London: Cassell.

Glina, M (2009) Democracy as morality: Using philosophical dialogue to cultivate safe learning communities. Analytical Teaching and Philosophical Practice, 29(1), pp. 31-38.

Glina, M (2015) Exploring prosocial behavior through structured philosophical dialogue: A quantitative evaluation. Democracy and Education,23(2), pp. 1-15.

Gregory, MR, Haynes, J, \& Murris, K (eds.) (2017) The Routledge international handbook of Philosophy for Children. London, UK, Routledge.

Haynes, F (2018) Trust and the community of inquiry. Educational Philosophy and Theory, 50(2), pp. 144-151.

Jackson, TE (2001) The art and craft of 'gently Socratic' inquiry. In AL Costa (ed) Developing minds: A resource book for teaching thinking. Virginia: Association for Supervision and Curriculum Development, pp. 459-465.

Jackson, TE (2004) Philosophy for Children Hawaii style-'On not being in a rush.' Thinking: The Journal of Philosophy for Children, 17(1 \& 2), pp. 4-8.

Jackson, TE (2012) Home grown. Educational Perspectives 44(1 \& 2), pp. 3-7.

Kyle, J (1987) Not a success story: Why Philosophy for Children did not take with gifted students in a summer school setting. Analytical Teaching and Philosophical Practice, 7(2), pp. 11-16.

Laverty, MJ \& Gregory, MR (2018) Ann Margaret Sharp: A life teaching community. In MR Gregory \& M Laverty (Eds) In community of inquiry with Ann Margaret Sharp: Childhood, philosophy and education. New York, NY, Routledge, pp. 1-17.

Leng, L (2015) The role of philosophical inquiry in helping high school students engage in learning and seeking meaning in lives. Honolulu, HI, University of Hawaii at Manoa.

Lipman, M. (2003) Thinking in education. Cambridge, UK, Cambridge University Press. 
Lipman, M (2008) A life teaching thinking. Montclair, NJ, The Institute for the Advancement of Philosophy for Children.

Lipman, M., Sharp, AM \& Oscanyan, FS (1980). Philosophy in the classroom. Philadelphia, PA, Temple University Press.

Makaiau, A, Wang, J, Ragoonaden, K \& Leng, L (2017) Empowering P4C research and practice through self-study: The philosophy for children Hawaii international journaling project. In MR Gregory, J Haynes \& K Murris (eds) The Routledge international handbook of Philosophy for Children. London, UK, Routledge, pp. 227235.

McCall, C \& Weijers, E (2017) Back to basics: A philosophical analysis of philosophy in philosophy with children. In MR Gregory, J Haynes \& K Murris (eds) The Routledge international handbook of Philosophy for Children. London, UK, Routledge, pp. 83-92.

Millett, S \& Tapper, A (2012). Benefits of collaborative philosophical inquiry in schools. Educational Philosophy and Theory, 44(5), pp. 546-567.

Reed-Sandoval, A \& Sykes, A (2017) Who talks? Who listens? Taking 'positionality' seriously in philosophy for children. In MR Gregory, J Haynes \& K Murris (eds) The Routledge international handbook of Philosophy for Children. London, UK, Routledge, pp. 219-226.

Sharp, AM (1987) What is a 'community of inquiry'? Journal of Moral Education, 16(1), pp. 37-45.

Sharp, AM (2007) The classroom community of inquiry as ritual: How we can cultivate wisdom. Critical and Creative Thinking, 15(1), pp. 3-14.

Sharp, AM (2009a) The Community of Inquiry as ritual participation. In E Marsal, T Dobashi \& B Weber (eds) Children philosophize worldwide: Theoretical and practical concepts. Frankfurt, Peter Lang, pp. 301-306.

Sharp, AM (2009b) Let's go visiting: Learning judgment making in a classroom community of inquiry. In E Marsal, T Dobashi \& B Weber (eds) Children 
philosophize worldwide: Theoretical and practical concepts. Frankfurt, Peter Lang, pp. 323-336.

Trickey, S \& Topping, K (2004) Philosophy for children: A systemic review. Research Papers in Education, 19(3), pp. 365-380.

Turgeon, W (1998) The reluctant philosopher: Causes and cures. Critical and Creative Thinking, 6(2), pp. 9-17.

Wang, JC (2018) Philosophy for children and Dewey's aesthetics: A teacher educator's self-study through narrative inquiry. In E Duthie, FG Mariyon, \& R Loro (eds) Family resemblance: Current trends in philosophy for children. Madrid, Anaya, pp. 70-81. 